\title{
Global distribution and variability of subsurface chlorophyll $a$ concentrations
}

\author{
Sayaka Yasunaka ${ }^{1}$, Tsuneo Ono ${ }^{2}$, Kosei Sasaoka ${ }^{1}$, and Kanako Sato ${ }^{1}$ \\ ${ }^{1}$ Research Institute for Global Change, Japan Agency for Marine-Earth Science and Technology, Yokosuka, 237-0061, Japan \\ ${ }^{2}$ Fisheries Resources Institute, Japan Fisheries Research and Education Agency, Yokohama, 236-8648, Japan
}

Correspondence: Sayaka Yasunaka (yasunaka@jamstec.go.jp)

Received: 14 September 2021 - Discussion started: 22 September 2021

Revised: 5 January 2022 - Accepted: 11 January 2022 - Published: 24 February 2022

\begin{abstract}
Chlorophyll $a(\mathrm{Chl} a)$ often exhibits a maximum concentration in the subsurface layer rather that at the surface. The depth of the Chl $a$ maximum primarily depends on the balance between light penetration from the surface and the nutrient supply from the deep ocean. However, a global map of subsurface $\mathrm{Chl} a$ concentrations based on observations has not been presented yet. In this study, we integrate Chl $a$ concentration data from recent biogeochemical floats and historical ship-based (and other) observations and present global maps of subsurface $\mathrm{Chl} a$ concentrations with related variables. The subsurface $\mathrm{Chl} a$ maximum was observed globally throughout the oceans: at depths greater than $80 \mathrm{~m}$ in the subtropics and tropics $\left(30^{\circ} \mathrm{S}\right.$ to $\left.30^{\circ} \mathrm{N}\right)$; in the $40-80 \mathrm{~m}$ depth range in the tropics, in the Southern Ocean (south of $40^{\circ} \mathrm{S}$ ), and at the midlatitudes $\left(30-40^{\circ} \mathrm{N} / \mathrm{S}\right.$ ) in the North Pacific; and at depths of less than $40 \mathrm{~m}$ in the northern subarctic (north of $40^{\circ} \mathrm{N}$ ). The observed maxima all lie below the mixed-layer depth for the entire year in the subtropics and tropics and during summer in the midlatitudes and the northern subarctic. The depths of the subsurface Chl $a$ maxima are greater than those of the photosynthetically active layer in the subtropics but shallower in the tropics and midlatitudes. In the subtropics, a seasonal increase in oxygen below the mixed layer implies substantial new biological production, which corresponds to $10 \%$ of the net primary production in that region. During El Niño, subsurface Chl $a$ concentrations are higher in the middle and eastern equatorial Pacific but lower to the west in comparison with La Niña, a pattern which is opposite to that on the surface. The spatiotemporal variability of the Chl $a$ concentrations described here has implications to not only for the biogeochemical cycling in the ocean but also for understanding the
\end{abstract}

thermal structure and dynamics of the ocean via absorption of shortwave radiation.

\section{Introduction}

Chlorophyll $a(\mathrm{Chl} a)$ concentrations in the ocean often exhibit a maximum value not at the surface but rather in the subsurface layer. The subsurface $\mathrm{Chl} a$ maximum is a widespread and common feature in various oceans in the tropics, subtropics, and subarctic (Anderson, 1969; Saijo et al., 1969; Furuya, 1990; Bhattathiri et al., 1996; Mann and Lazier, 1996). The same finding was also recently reported in the Arctic Ocean and the Southern Ocean (Ardyna et al., 2013; Baldry et al., 2020). Substantial primary production is also observed in the subsurface, although the relationship between $\mathrm{Chl} a$ concentrations, biological biomass, and primary production is not simple, and the subsurface Chl $a$ maximum often represents a photoacclimation response in phytoplankton (Kitchen and Zaneveld, 1990; Campbell and Vaulot, 1993; Goldman, 1988; Fennel and Boss, 2003; Matsumoto and Furuya, 2011; Cornec et al., 2021). The depth of the Chl $a$ maximum primarily depends on the balance between light penetration from the surface and nutrient supply from the deep ocean (Cullen, 2015) but also partially depends on light-dependent grazing by zooplankton near the surface (Moeller et al., 2019).

Chl $a$ concentrations have physical effects in the ocean because Chl $a$ absorbs shortwave radiation, which leads to ocean warming followed by a modified thermal structure and ocean dynamics (Lewis et al., 1990; Siegel et al., 1995). Modeling studies have indicated that the interannual varia- 


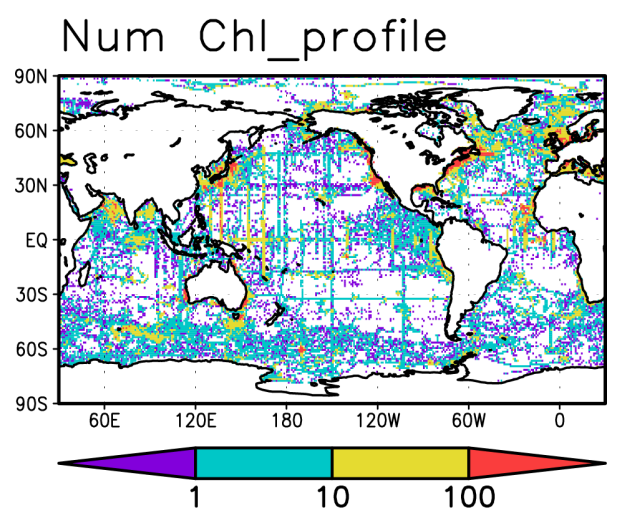

Figure 1. Number of Chl $a$ concentration profiles in different areas.

tion in subsurface Chl $a$ concentrations is an important parameter for accurate El Niño simulations (Jochum et al., 2010; Kang et al., 2017).

Using satellite-retrieved ocean surface $\mathrm{Chl} a$ concentrations, many studies have described the basin-scale spatial distribution and temporal variation of surface $\mathrm{Chl} a$ (e.g., Dunstan et al., 2018; Lin et al., 2014; Sasaoka et al., 2011); however, those features have not been described in detail for subsurface $\mathrm{Chl} a$. Although several studies have parameterized the vertical profile of $\mathrm{Chl} a$ concentrations and reproduced subsurface Chl $a$ maxima (Ardyna et al., 2013; Uitz et al., 2006), their main purpose was to estimate depthintegrated $\mathrm{Chl} a$ and primary production. Recently, biogeochemical Argo floats with Chl $a$ sensors have revealed the occurrence of the subsurface $\mathrm{Chl} a$ maxima and their relationship to phytoplankton biomass across the world's oceans (Cornec et al., 2021). However, subsurface $\mathrm{Chl} a$ data derived from a single data source does not have sufficient coverage to illustrate the wider picture; therefore, a global map of observed subsurface $\mathrm{Chl} a$ concentration is still needed. Global maps of subsurface Chl $a$ maxima have thus far been based on statistical estimates or numerical models (Mignot et al., 2014; Masuda et al., 2021), and only surface Chl $a$ concentrations have been used to validate numerical models (e.g., Séférian et al., 2020).

Here, we synthesize Chl $a$ concentration data from recent biogeochemical floats and from historical ship-based (and other) observations and present global maps of subsurface Chl $a$ concentrations. We then present the seasonal and interannual variability of the subsurface $\mathrm{Chl} a$ concentrations in relation to other variables in the world's oceans.

\section{Data}

Chl $a$ measurements were extracted from the World Ocean Database 2018 (WOD2018; Boyer et al., 2018) and the Global Ocean Data Analysis Project version 2.2019 Release (GLODAPv2.2019; Olsen et al., 2019). These measurements were taken from bottle samples, conductivity-temperaturedepth (CTD) fluorescence, underway CTD fluorescence, profiling floats, gliders, and drifting buoys. Data from the biogeochemical Argo floats are included in WOD2018 under the category of measurements from profiling floats. The total number of Chl $a$ measurements is 114107161 from 737469 profiles measured between 1932 and 2020 in the upper $300 \mathrm{~m}$ (Table 1). The data are globally distributed across the oceans (Fig. 1). Most of the data for the open ocean are from bottle samples, CTD fluorescence, and profiling floats (Fig. S1).

$\mathrm{Chl} a$ data often include several high values $\left(>3 \mathrm{mg} \mathrm{m}^{-3}\right)$ that represent erroneous data or data that reflect short-term and small-scale extreme conditions (Fig. S2a). We conducted quality control efforts to reduce the effect of such data, as they might otherwise detract from our purpose of determining large-scale distribution patterns in the open ocean. Although different types of data errors are present among the different data sources, statistical quality control measures using a limited number of data did not work effectively, and thus we instead uniformly treated the data from all data sources. The quality control measures used are as follows.

1. We binned the Chl $a$ measurements from each profile into depths of $5(0-5 \mathrm{~m}), 10(5-15 \mathrm{~m}), 20(15-$ $25 \mathrm{~m}), 30(25-40 \mathrm{~m}), 50(40-62.5 \mathrm{~m}), 75(62.5-87.5 \mathrm{~m})$, 100 (87.5-112.5 m), 125 (112.5-137.5 m), 150 (137.5$175 \mathrm{~m})$, and $200 \mathrm{~m}(175-250 \mathrm{~m})$.

2. We calculated the long-term mean and its standard deviation within ranges of $\pm 5^{\circ}$ latitude, $\pm 10^{\circ}$ longitude, and \pm 1 month (regardless of the year) for each $1^{\circ} \times 1^{\circ} \times 1$ month grid cell at each depth.

3. We flagged data that differed by more than 3 standard deviations from the long-term mean in each grid cell at each depth.

4. We eliminated profiles in which more than half of all data had been flagged in step 3 .

5. We eliminated profiles in which more than half of all profiles within $\pm 10^{\circ}$ of the latitude and longitude and \pm 1 month had been eliminated in step 4 .

This procedure identified approximately $1 \%$ of the measurements as belonging to erroneous or extreme profiles (Table 1). Data with high values were extensively eliminated, and $85 \%$ of the eliminated data have values of $>3 \mathrm{mg} \mathrm{m}^{-3}$ (Fig. S2b). The eliminated data were mostly located in coastal regions and partly scattered in the open oceans (not shown here). The ratio of eliminated data is slightly larger in data from underway CTD fluorescence and bottle samples. This is likely because they included more uncalibrated and historical data (Table 1).

For the remaining data after quality control, we calculated monthly means of Chl $a$ concentrations in $1^{\circ} \times 1^{\circ}$ grid cells at each depth. We also calculated the depth of the Chl $a$ 
Table 1. Number of chlorophyll $a(\mathrm{Chl} a)$ measurements and profiles from each data source with percentages eliminated by quality control.

\begin{tabular}{lrrr}
\hline Platform & No. of measurements & No. of profiles & Eliminated \% \\
\hline Bottle sample & 1292565 & 179277 & $2.2 \%$ \\
CTD fluorescence & 23824711 & 89541 & $0.9 \%$ \\
Underway CTD fluorescence & 1086359 & 19251 & $3.0 \%$ \\
Profiling float & 11383247 & 67903 & $0.3 \%$ \\
Glider & 75724059 & 375421 & $0.3 \%$ \\
Drifting buoy & 796220 & 6076 & $0.3 \%$ \\
\hline Total & 114107161 & 737469 & $1.1 \%$ \\
\hline
\end{tabular}

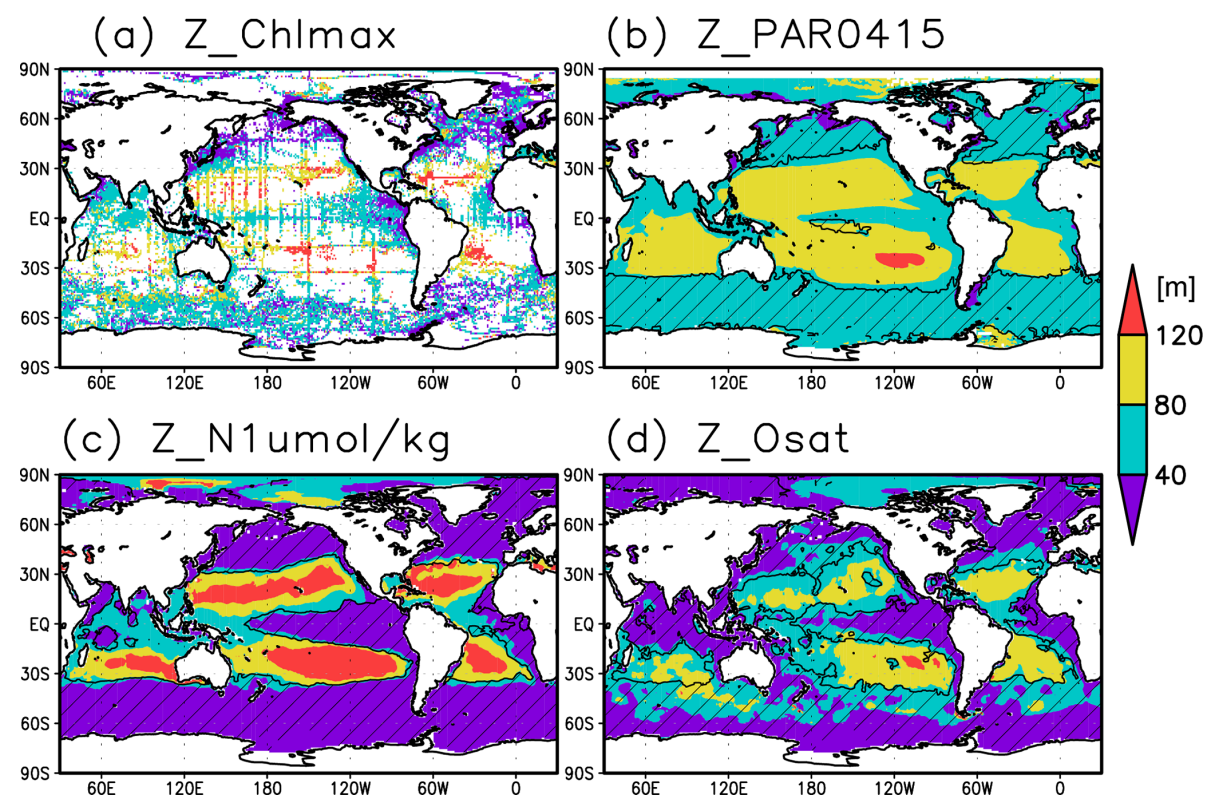

Figure 2. Depths of (a) the chlorophyll $a(\mathrm{Chl} a)$ maximum, (b) the photosynthetically active layer $\left(>0.415 \mathrm{~mol} \mathrm{~m}^{-2} \mathrm{~d}^{-1}\right.$ of photosynthetically available radiation), (c) the nitrate-depleted layer $\left(<1 \mu \mathrm{mol} \mathrm{kg}{ }^{-1}\right.$ of nitrate), and (d) the oxygen-oversaturated layer. The hatched areas show regions in which the mixed layer is deeper than the photosynthetically active layer in (b), the nitrate-depleted layer in (c), and the oxygen-oversaturated layer in (d).

maximum in each individual profile that included data from more than five different depths, and then binned them into $1^{\circ} \times 1^{\circ} \times 1$-month grid cells. The average sampling depth in-

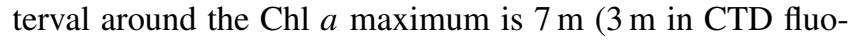
rescence and profiling floats, and $16 \mathrm{~m}$ in bottle samples).

Satellite-derived surface $\mathrm{Chl} a$ concentrations, euphoticlayer depths ( $1 \%$ light level, i.e., Z_eu), and surface values of photosynthetically available radiation (PAR) with a $1^{\circ} \times 1^{\circ}$ monthly resolution since September 1997 were obtained from the GlobColour project website (GlobColour_R2018; http://hermes.acri.fr/index.php, last access: 8 February 2022; Frouin et al., 2003; Maritorena et al., 2010; Morel et al., 2007). We estimated the PAR within the water column using the empirical relationship between $Z_{-}$eu and the surface PAR the same way as in Ito et al. (2015). The PAR at a depth of $z$ was calculated as

$\operatorname{PAR}(z)=0.98 \times \operatorname{PAR}(0) \times \exp (-k z)$, where $k$ is the light-attenuation coefficient within the water column derived from

$k=-\log (0.01) /$ Z_eu.

The coefficient 0.98 in Eq. (1) is the transmission rate into the ocean used by Boss and Behrenfeld (2010). We then defined photosynthetically active layer as having > $0.415 \mathrm{~mol} \mathrm{~m}^{-2} \mathrm{~d}^{-1}$ of PAR as per Boss and Behrenfeld (2010).

Monthly fields of net primary production (NPP) were obtained from the Ocean Productivity website with a spatial resolution of $1 / 6^{\circ} \times 1 / 6^{\circ}$ and were calculated using the vertically generalized production model of Behrenfeld and Falkowski (1997). We used climatological means of oxygen concentrations, oxygen saturation ratios, and nitrate concentrations in the World Ocean Atlas 2018 (WOA2018; Garcia et al., 2018a, b). We also used the climatological mean 
(a) $\mathrm{Chl} 15^{\circ} \mathrm{N}-30^{\circ} \mathrm{N}$

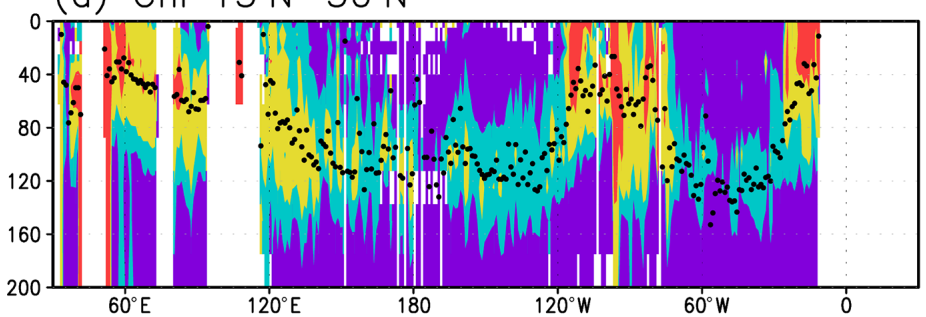

(b) $\mathrm{ChI} 2^{\circ} \mathrm{S}-2^{\circ} \mathrm{N}$

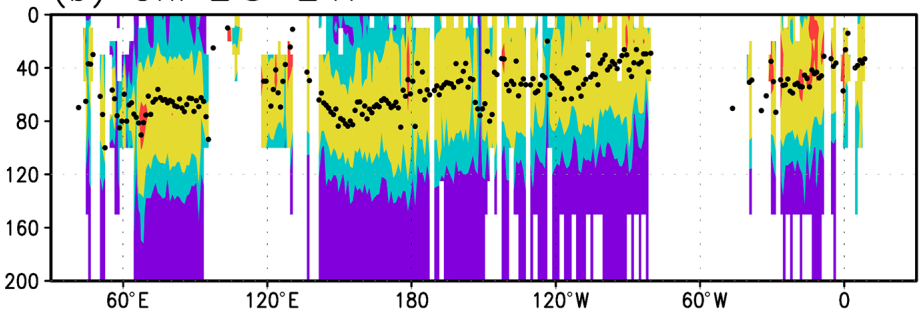

(c) $\mathrm{Chl} 35^{\circ} \mathrm{S}-20^{\circ} \mathrm{S}$

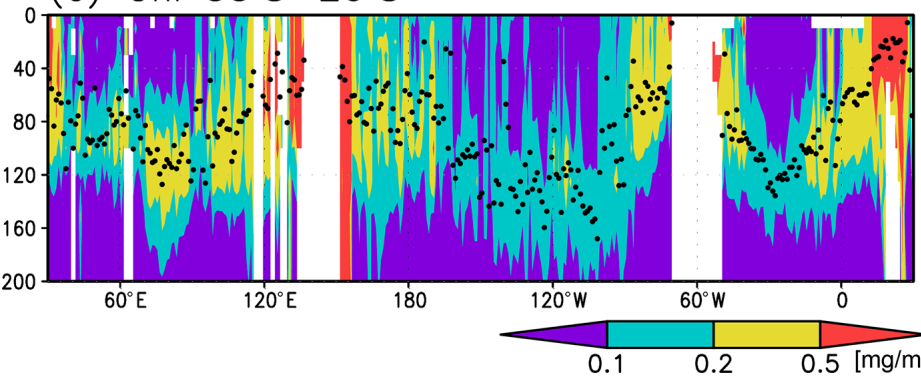

(d) $\mathrm{Chl} 60^{\circ} \mathrm{E}-90^{\circ} \mathrm{E}$

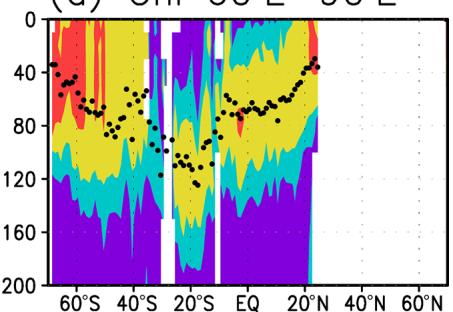

(e) $\mathrm{Chl} 160^{\circ} \mathrm{W}-130^{\circ} \mathrm{W}$

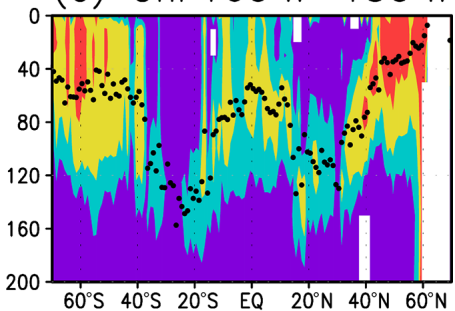

(f) $\mathrm{Chl} 50^{\circ} \mathrm{W}-20^{\circ} \mathrm{W}$

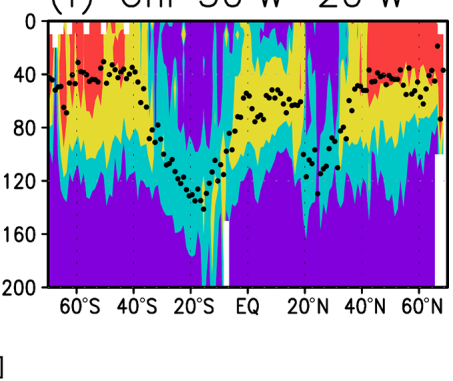

Figure 3. Cross sections of chlorophyll $a\left(\mathrm{Chl} a\right.$ ) concentrations at (a) $15-30^{\circ} \mathrm{N}$ (northern subtropics), (b) $2^{\circ} \mathrm{S}$ to $2^{\circ} \mathrm{N}$ (tropics), (c) $35-$ $20^{\circ} \mathrm{S}$ (southern subtropics), (d) $60-90^{\circ} \mathrm{E}$ (the Indian Ocean), (e) $160-130^{\circ} \mathrm{W}$ (the Pacific Ocean), and (f) $50-20^{\circ} \mathrm{W}$ (the Atlantic Ocean). The black dots indicate the depth of the $\mathrm{Chl} a$ maximum.
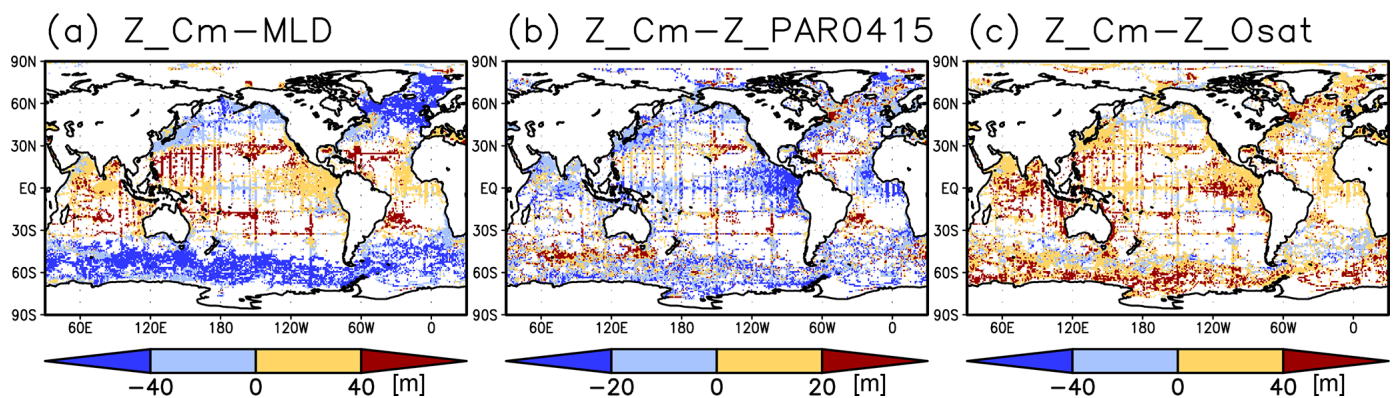

Figure 4. Depth differences between the chlorophyll $a(\mathrm{Chl} a)$ maximum and (a) the mixed layer, (b) the photosynthetically active layer ( $>0.415 \mathrm{~mol} \mathrm{~m}^{-2} \mathrm{~d}^{-1}$ of photosynthetically available radiation), and (c) the oxygen-oversaturated layer.

of mixed-layer depths (the depth at which $\sigma_{\theta}$ changes by 0.125 compared to that at the surface) produced by JAMSTEC (MILA_GPV; Hosoda et al., 2010; missing data were interpolated using data from the surrounding grids). Using a mixed-layer depth defined by a $\sigma_{\theta}$ change of 0.03 produced very similar results. We show the results using the mixedlayer depth with a change from the surface $\sigma_{\theta}$ of 0.125 here.

We calculated the Niño 3.4 index (sea surface temperatures over $5^{\circ} \mathrm{N}$ to $5^{\circ} \mathrm{S}, 170-120^{\circ} \mathrm{W}$ ) as an indicator of
El Niño and La Niña using the Hadley Centre Sea Ice and Sea Surface Temperature data set (HadISST; https:// www.metoffice.gov.uk/hadobs/hadisst/, last access: 8 February 2022; Rayner et al., 2003). El Niño or La Niña were originally defined by periods when the Niño 3.4 index exceeds $\pm 0.4^{\circ} \mathrm{C}$ for 6 months or longer (Trenberth, 1997). Here, El Niño or La Niña is taken to refer to all positive or negative Niño 3.4 indices, respectively, because the amount of subsurface Chl $a$ data would otherwise be limited. 

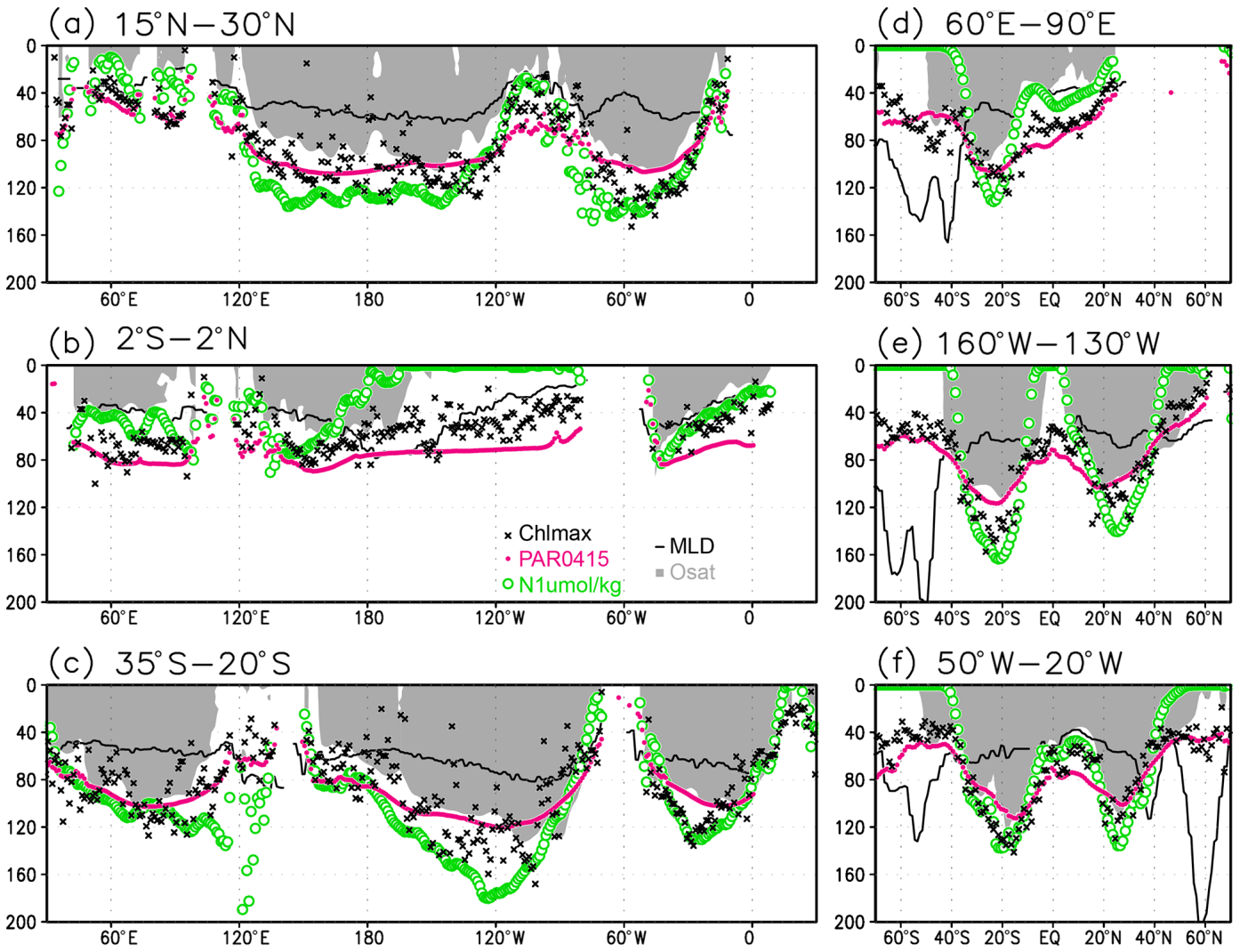

Figure 5. Depths of the chlorophyll $a$ (Chl $a$ ) maximum (black crosses), photosynthetically active layer $\left(>0.415 \mathrm{~mol} \mathrm{~m}^{-2} \mathrm{~d}^{-1}\right.$ of photosynthetically available radiation; magenta dots), nitrate-depleted layer $\left(<1 \mu \mathrm{mol} \mathrm{kg}{ }^{-1}\right.$ of nitrate; open green circles), mixed layer (black line), and oxygen-oversaturated layer (gray shading) at (a) $15-30^{\circ} \mathrm{N}$ (northern subtropics), (b) $2^{\circ} \mathrm{S}$ to $2^{\circ} \mathrm{N}$ (tropics), (c) $35-20^{\circ} \mathrm{S}$ (southern subtropics), (d) 60-90 E (Indian Ocean), (e) 160-130 W (Pacific Ocean), and (f) 50-20 W (Atlantic Ocean).

\section{Results}

\subsection{Climatological mean state}

Figures $2 \mathrm{a}$ and 3 show the depths of the Chl $a$ maxima and cross sections of $\mathrm{Chl} a$ concentrations from the qualitycontrolled data, respectively. We selected the central latitudinal and longitudinal bands of the subtropics, the tropics, the Indian Ocean, the Pacific Ocean, and the Atlantic Ocean in Fig. 3. The Chl $a$ concentrations exhibit subsurface maxima across the world's oceans, at depths below $80 \mathrm{~m}$ in the subtropics; at 40-80 m depth in the tropics, the Southern Ocean, and the midlatitudes in the North Pacific; and at depths above $40 \mathrm{~m}$ in the northern subarctic. The subsurface maximum is deeper than $120 \mathrm{~m}$ in the central subtropics and reaches $150 \mathrm{~m}$ at approximately $25^{\circ} \mathrm{S}, 100^{\circ} \mathrm{W}$ in the South Pacific. The subsurface maxima in the subtropics and the tropics were deeper than the mixed layer (Figs. 4a and 5). In the Southern Ocean and the northern North Atlantic, several patches of subsurface maxima were observed at depths greater than $80 \mathrm{~m}$, but these depths are generally shallower than the mixed-layer depth (Figs. 2a, 4a, and 5d-f). The ranges of $\mathrm{Chl} a$ concentration at the subsurface maxima are $0.1-0.2 \mathrm{mg} \mathrm{m}^{-3}$ in the subtropics, $0.2-0.5 \mathrm{mg} \mathrm{m}^{-3}$ in the tropics, and $>0.5 \mathrm{mg} \mathrm{m}^{-3}$ in the subarctic (Figs. 3 and $6 \mathrm{a}$ ).

The long-term mean of the photosynthetically active layer depth is greater than $80 \mathrm{~m}$ in the subtropics and deeper than $40 \mathrm{~m}$ in other regions (Fig. 2b). It is also greater than the mixed-layer depth in the subtropics, the Arctic Ocean, and the tropics, but it is shallower in the northern subarctic and the Southern Ocean (Figs. 2b and 5). The PAR values at the subsurface $\mathrm{Chl} a$ maxima are generally stronger than $1 \mathrm{~mol} \mathrm{~m}^{-2} \mathrm{~d}^{-1}$ in the subarctic and in the tropics (Fig. 6b). The spatial distribution of the photosynthetically active layer depth is similar to that of the subsurface Chl $a$ maximum depth (Fig. 2a, b), but substantial differences were observed (Fig. 4b). For example, the subsurface $\mathrm{Chl} a$ maximum is deeper than the photosynthetically active layer in the subtropics and at $40-60^{\circ} \mathrm{S}$ in the Indian sector, but it is shallower than the photosynthetically active layer depth in other regions.

Nitrate concentrations in the surface layer were less than $1 \mu \mathrm{mol} \mathrm{kg}{ }^{-1}$ in places with a deep subsurface Chl $a$ maximum (Figs. 2c and 5). In these areas, the nitrate concentrations at the depth of the subsurface Chl $a$ maximum were also low, while nitrate concentrations are greater than 
(a) Chl_ChImax

(b) PAR_Chlmax

(c) N_Chlmax
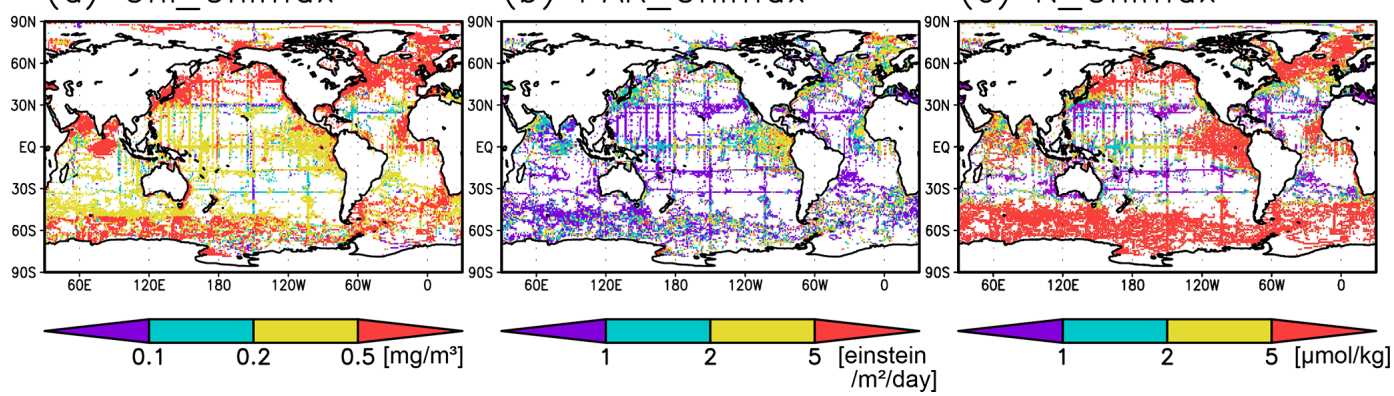

Figure 6. (a) Chlorophyll $a(\mathrm{Chl} a)$ concentrations, (b) photosynthetically available radiation, and (c) nitrate concentrations at the Chl $a$ maximum depth.

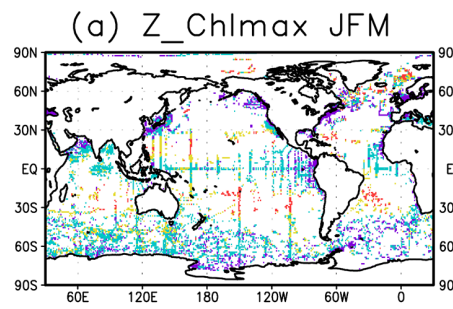

(b) Z_PAR0415 JFM

(c) Z_Osat JFM

(a) Z_ChImax JAS
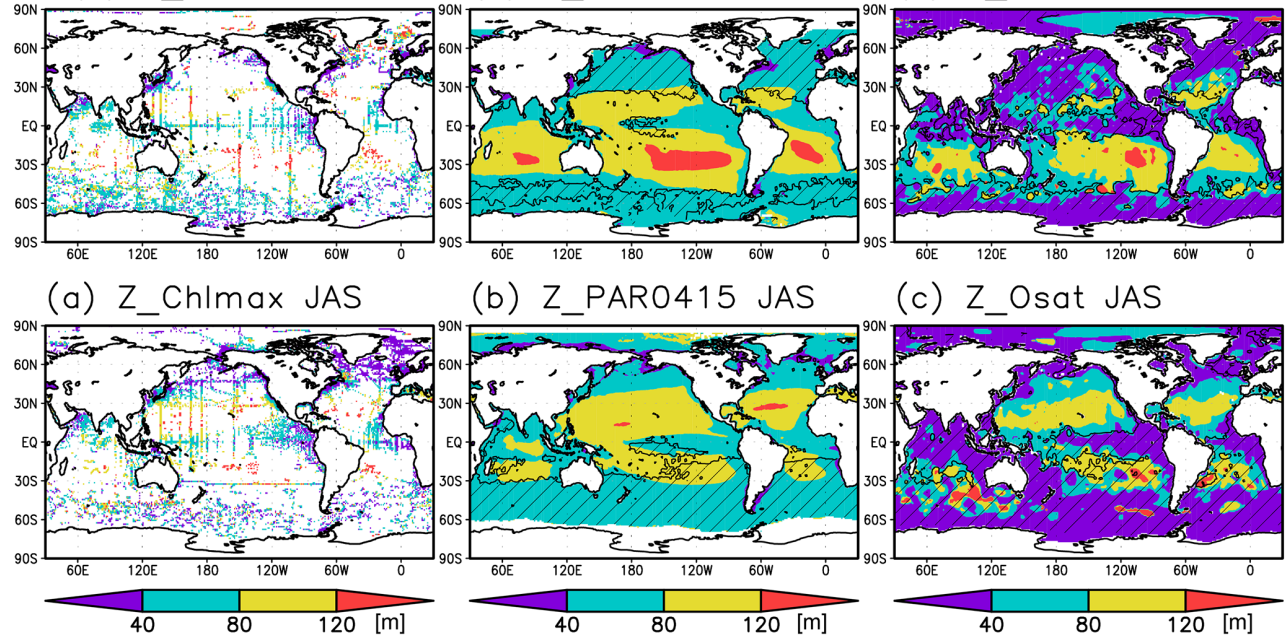

(b) Z_PAR0415 JAS

(c) Z_Osat JAS
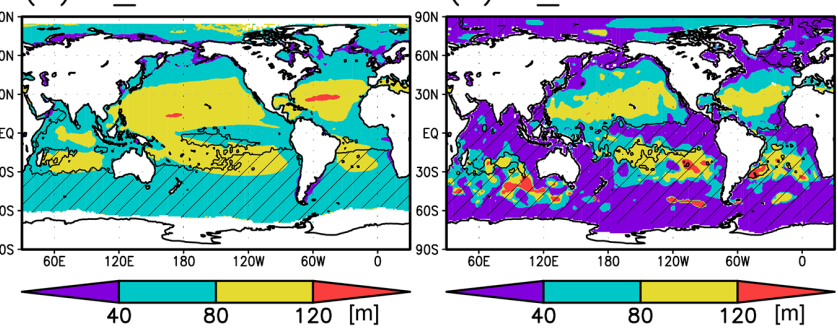

(d) Z_Cm JFM-JAS

(e) Z_P415 JFM-JAS
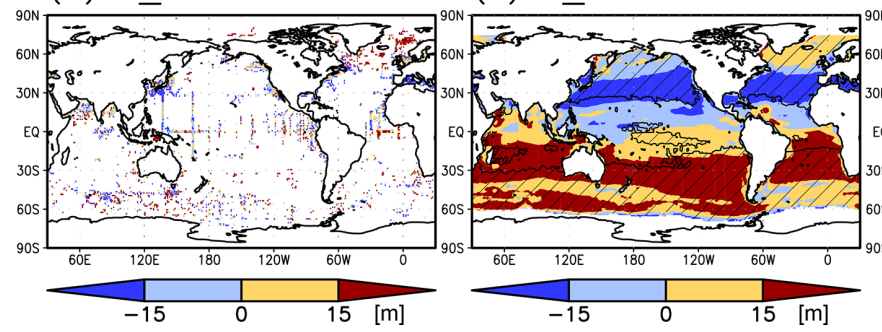

(f) Oxy JFM-JAS

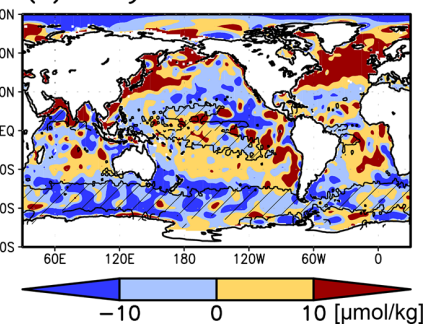

Figure 7. (a-c) Depths of the chlorophyll $a(\mathrm{Chl} a)$ maximum, photosynthetically active layer $\left(>0.415 \mathrm{~mol} \mathrm{~m}^{-2} \mathrm{~d}^{-1}\right.$ of photosynthetically available radiation), and oxygen-oversaturated layer in January-March (JFM) (top row) and July-September (JAS) (middle row), respectively. (d-f) Differences between the Chl $a$ maximum depth, photosynthetically active layer depth, and dissolved oxygen concentrations at 50-150 m during JFM compared to those in JAS. The hatched areas indicate a mixed layer deeper than the photosynthetically active layer in (b), the oxygen saturation layer in (c), the photosynthetically active layer in winter (JFM in the Northern Hemisphere and JAS in the Southern Hemisphere) in (e), and $50 \mathrm{~m}$ in summer (JAS in the Northern Hemisphere and JFM in the Southern Hemisphere) in (f).

$5 \mu \mathrm{mol} \mathrm{kg}{ }^{-1}$ in the subarctic and eastern tropics but less than $1 \mu \mathrm{mol} \mathrm{kg}{ }^{-1}$ in the subtropics and the Arctic Ocean (Fig. 6c).

The subtropics are oversaturated with oxygen down to depths of at least $40 \mathrm{~m}$ and deeper than $80 \mathrm{~m}$ in some places (Figs. 2d and 5). The lower limit of oxygen oversaturation in the subtropics mostly occurs below the mixed layer and above the subsurface Chl $a$ maximum (Figs. $2 \mathrm{~d}$ and $4 \mathrm{c}$ ).

\subsection{Seasonal variation}

The subsurface Chl $a$ maximum in the subtropics was observed to occur below the mixed layer in both winter and summer (Figs. 7a and 8). The photosynthetically active layer is deeper than the mixed layer during both seasons between $20^{\circ} \mathrm{N}$ and $30^{\circ} \mathrm{S}$ in the Indian Ocean and the western $\mathrm{Pa}$ - 

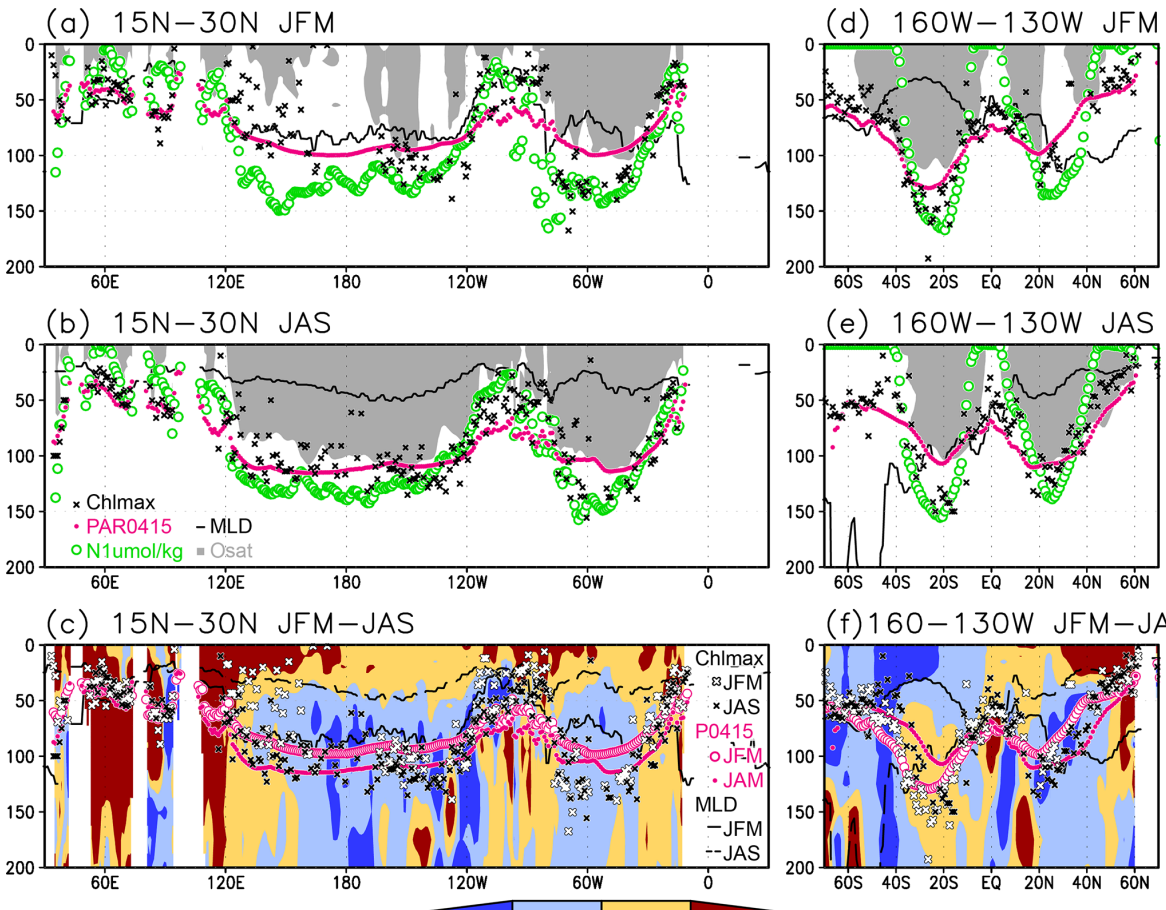

$30 \mathrm{~N}$ JFM-JAS
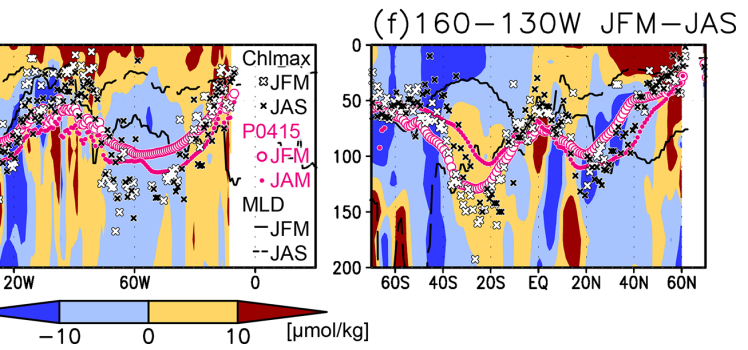

Figure 8. (a, b) Depths of the chlorophyll $a$ (Chl a) maximum (black crosses), photosynthetically active layer $\left(>0.415 \mathrm{~mol} \mathrm{~m}^{-2} \mathrm{~d}^{-1}\right.$ of photosynthetically available radiation, shown as magenta dots), nitrate-depleted layer $\left(<1 \mu \mathrm{mol} \mathrm{kg}{ }^{-1}\right.$ of nitrate, shown as open green circles), mixed layer (black line), and oxygen-oversaturated layer (gray shading) at $15-30^{\circ} \mathrm{N}$ (northern subtropics) in (a) January-March (JFM) and (b) July-September (JAS). (c) Difference between dissolved oxygen concentrations during JFM and JAS (color scale) and depths of the Chl $a$ maximum, photosynthetically active layer, and mixed layer in JFM and JAS (white and black crosses, open and solid magenta dots, and solid and dashed black lines, respectively) at $15-30^{\circ}$ N. Panels (d-f) are the same as (a-c) but are at $160-130^{\circ} \mathrm{W}(\mathrm{Pacific}$ Ocean).

cific, between $20^{\circ} \mathrm{N}$ and $20^{\circ} \mathrm{S}$ in the Atlantic Ocean and the eastern Pacific, and in the whole summer hemisphere except for $40-60^{\circ} \mathrm{S}$ (Figs. $7 \mathrm{~b}$ and 8 ). The photosynthetically active layer is deeper in summer than in winter in nearly all areas except for the North Atlantic (Fig. 7e). This summer deepening is more than $15 \mathrm{~m}$ in the $20-40^{\circ}$ latitudinal bands in both hemispheres (Figs. 7e and 8f). The seasonal differences in the Chl $a$ maximum depths exhibit the same tendencies as the photosynthetically active layer (Fig. 7d). Below the mixed layer, oxygen is oversaturated north of $10^{\circ} \mathrm{N}$ and at $10-45^{\circ} \mathrm{S}$ in summer (Figs. 7c, 8b, d, e). The subsurface oxygen concentrations are higher in summer than in winter at latitudes of approximately $15-40^{\circ}$ (Figs. 7f, 8c, f).

The subsurface $\mathrm{Chl} a$ maximum being deeper than the mixed layer was observed to be stable in the subtropics and tropics $\left(30^{\circ} \mathrm{S}\right.$ to $\left.30^{\circ} \mathrm{N}\right)$, was seen only in summer at midlatitudes $\left(30\right.$ to $\left.40^{\circ}\right)$, and occurred rarely at $45-60^{\circ} \mathrm{S}$ in the Southern Ocean and in the northern North Atlantic (north of $45^{\circ} \mathrm{N}$ ) (Figs. 9a and 10). The percentage of months with a deeper photosynthetically active layer than the mixed layer has a similar pattern to the percentage of months deeper the subsurface Chl $a$ maximum than the mixed layer, except in the northern North Atlantic (Fig. 9b). At the midlatitudes, the Chl $a$ concentrations were high $\left(>0.3 \mathrm{mg} \mathrm{m}^{-3}\right)$ throughout the entire mixed layer during winter and remained high at the subsurface but became low on the surface in summer, when the mixed layer becomes shallow (Fig. 10c). At $45-60^{\circ} \mathrm{S}$ in the Southern Ocean, as well as in the northern North Atlantic, the Chl $a$ concentrations in the mixed layer were high in summer and low in winter, while the subsurface $\mathrm{Chl} a$ maximum occurred around the mixed layer depth in summer and within the mixed layer in winter (Fig. 10h, i). In the subarctic North Pacific, the seasonal cycle of the Chl $a$ concentrations is similar to that in the subarctic North Atlantic, although the surface $\mathrm{Chl} a$ concentration is relatively low and the subsurface $\mathrm{Chl} a$ maximum appears at a depth below the mixed layer in midsummer (Fig. 10g).

\subsection{El Niño-Southern Oscillation (ENSO)-related variation}

A subsurface Chl $a$ maximum along the Equator can be seen in the photosynthetically active layer during El Niño and La Niña (Fig. 11a, b). Below $40 \mathrm{~m}$, which is approximately the mixed-layer depth in that area, the Chl $a$ concentration is lower west of $160^{\circ} \mathrm{E}$ during El Niño but higher east of $170^{\circ} \mathrm{W}$ (Fig. 11c). Although the difference in the Chl $a$ concentrations between El Niño and La Niña is noisy above 

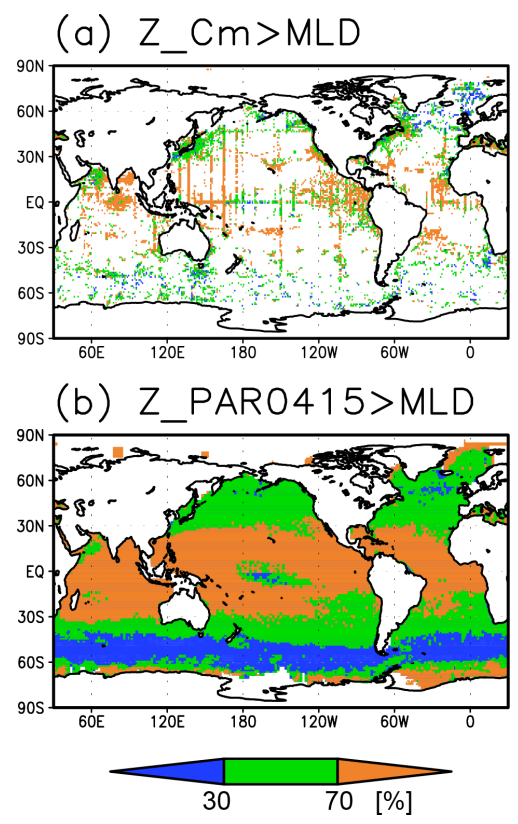

Figure 9. Percentage of months when (a) the chlorophyll $a$ (Chl $a$ ) maximum and (b) the photosynthetically active layer (> $0.415 \mathrm{~mol} \mathrm{~m}^{-2} \mathrm{~d}^{-1}$ of photosynthetically available radiation) were deeper than the mixed layer. Data in grids with only one datum were omitted.

$40 \mathrm{~m}$, most of the significant difference is negative east of $150^{\circ}$ E (Fig. 11c). Satellite-derived surface Chl $a$ concentrations show lower values during El Niño than those during $\mathrm{La}$ Niña east of $150^{\circ} \mathrm{E}$ (Fig. 12a). Surface PAR is lower (higher) to the east (west) of $150^{\circ} \mathrm{E}$ during El Niño (Fig. 12b), while the photosynthetically active layer deepens by several meters during El Niño east of $150^{\circ} \mathrm{E}$ (Fig. 12c). The lower and higher subsurface $\mathrm{Chl} a$ concentrations to the west and east of $160^{\circ} \mathrm{E}$ during El Niño occur mainly at the depths of 60$120 \mathrm{~m}$, which corresponds well with the base of the photosynthetically active layer (Figs. 11c and 12c).

\section{Discussion}

The spatial distribution of the subsurface $\mathrm{Chl} a$ maximum in the subtropics seen in this study (Figs. 2a and 3) corresponds to the bowl-shaped thermocline structure of the subtropical gyre (Pedlosky, 1990). The deep thermocline in the central subtropics inhibits nutrient supply to the surface, causing low nutrient levels and $\mathrm{Chl} a$ concentrations there.

Uitz et al. (2006) explained that a deeper subsurface $\mathrm{Chl} a$ maximum corresponds to lower surface $\mathrm{Chl} a$ concentrations because light proceeds downward until it is absorbed by chlorophyll. Our study demonstrates that the depth of the subsurface Chl $a$ maximum is roughly consistent with the depth of the photosynthetically active layer throughout the world's oceans (Fig. 2a, b). However, Chl $a$ concentrations in the central subtropics exhibit a maximum below the photosynthetically active layer (Figs. $4 \mathrm{~b}$ and 5) because of the very low nutrient concentrations at the surface and dispersal of light down to a layer in which nutrients are available (Beckmann and Hense, 2007). Photoacclimation also often allows Chl $a$ to increase in the low PAR layer (Cornec et al., 2021; Masuda et al., 2021). When nutrients are available at shallow depths, $\mathrm{Chl} a$ displays maximum concentrations above the base of the photosynthetically active layer, as in the tropics and subarctic (Figs. 4 and 5). Note that the Chl $a$ concentrations are still significant below the maximum, including those below the photosynthetically active layer in the tropics and subarctic (Fig. 3).

The subsurface $\mathrm{Chl} a$ maxima in the global oceans can be categorized into three types depending on their seasonal cycles: (A) a year-round stable maximum below the mixed layer in the subtropics and tropics $\left(30^{\circ} \mathrm{S}\right.$ to $\left.30^{\circ} \mathrm{N}\right)$, (B) a maximum below the mixed layer in summer and within the mixed layer during winter in the midlatitudes $\left(30\right.$ to $40^{\circ}$ ), and (C) a maximum within the mixed layer at $45-60^{\circ} \mathrm{S}$ in the Southern Ocean and the northern North Atlantic (north of $45^{\circ} \mathrm{N}$ ) (Figs. 9 and 10). These categories also correspond to the seasonal cycle of surface $\mathrm{Chl} a$, which is subject to nutrient limitations and is low in all seasons in region $\mathrm{A}$ (Fig. 10a, b, d-f). In region B, nutrients are supplied by winter mixing, and winter blooms occur in the mixed layer; in contrast, surface nutrients get depleted, and the main body of $\mathrm{Chl} a$ is retained in the subsurface during summer (Fig. 10c). In region $\mathrm{C}, \mathrm{Chl} a$ concentrations in the mixed layer increase after shallowing of the mixed layer when there is sufficient light in summer (Fig. 10h, i). These features are consistent with regional studies reported in the literature (e.g., Baldry et al., 2020; Fujiki et al., 2020; Mignot et al., 2014; Sverdrup, 1953). The latitudinal dependence of the subsurface $\mathrm{Chl} a$ maxima occurrence was also noted by Cornec et al. (2021). The low surface $\mathrm{Chl} a$ concentrations and subsurface $\mathrm{Chl} a$ maxima below the mixed layer in midsummer in the subarctic North Pacific (Fig. 10g) are due to summer iron limitation at the surface (Martin and Fitzwater, 1988; Nishioka and Obata, 2017; Nishioka et al., 2020). South of $60^{\circ} \mathrm{S}$ in the western Indian sector of the Southern Ocean, the subsurface Chl $a$ maximum is deeper than the mixed layer (Fig. 4a), which is consistent with the subsurface $\mathrm{Chl} a$ maximum following sea ice retreat reported by Gomi et al. (2007).

Data on subsurface fluorescence maxima have been sometimes reported without subsurface Chl $a$ maxima (Falkowski and Kolber, 1995; Biermann et al., 2015). Data from profiling floats in particular have potentially suffered from fluorescence quenching at surface (Xing et al., 2012). To investigate the subsurface fluorescence maximum, we examined the subsurface $\mathrm{Chl} a$ maximum from each data source. The area-averaged Chl $a$ concentrations and the subsurface $\mathrm{Chl} a$ maximum show similar seasonal cycles in data from both bottle samples and profiling floats (Figs. S3 and S4). In the Southern Ocean, the subarctic North Atlantic, and the subarc- 

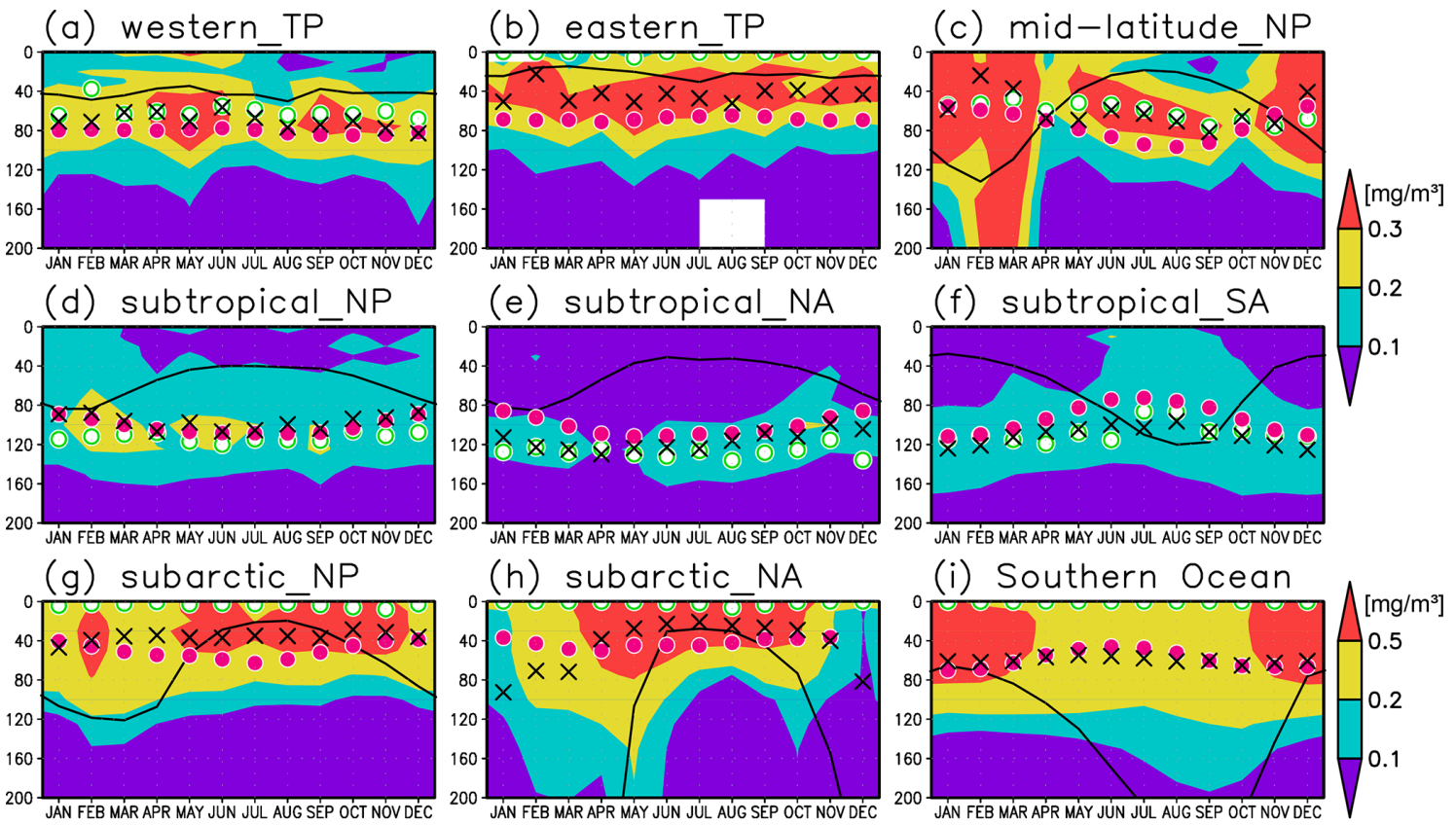

XChlmax OPAR0415 ON1umol/kg

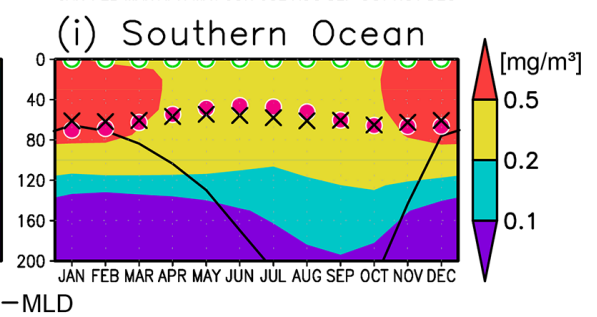

Figure 10. Seasonal evolution of chlorophyll $a(\mathrm{Chl} a)$ concentrations with the Chl $a$ maximum (black crosses), $0.415 \mathrm{~mol} \mathrm{~m}^{-2} \mathrm{~d}^{-1}$ of photosynthetically available radiation (magenta dots), $1 \mu \mathrm{mol} \mathrm{kg}{ }^{-1}$ of nitrate (open green circles), and the mixed layer (solid black line) at (a) $2^{\circ} \mathrm{S}-2^{\circ} \mathrm{N}, 120-170^{\circ} \mathrm{E}$ (western tropical Pacific); (b) $2^{\circ} \mathrm{S}-2^{\circ} \mathrm{N}, 120-90^{\circ} \mathrm{W}$ (eastern tropical Pacific); (c) $30-40^{\circ} \mathrm{N}, 150-130^{\circ} \mathrm{W}$ (midlatitude North Pacific); (d) $10-30^{\circ} \mathrm{N}, 120^{\circ} \mathrm{E}-120^{\circ} \mathrm{W}$ (subtropical North Pacific); (e) $15-30^{\circ} \mathrm{N}, 70-30^{\circ} \mathrm{W}$ (subtropical North Atlantic); (f) $30-10^{\circ} \mathrm{S}, 50-0^{\circ} \mathrm{W}$ (subtropical South Atlantic); (g) $40-55^{\circ} \mathrm{N}, 160^{\circ} \mathrm{E}-155^{\circ} \mathrm{W}$ (subarctic North Pacific); (h) $50-70^{\circ} \mathrm{N}, 30-0^{\circ} \mathrm{W}$ (subarctic North Atlantic); and (i) $60-45^{\circ} \mathrm{S}$ (Southern Ocean).

tic North Pacific, the subsurface Chl $a$ maximum within the mixed layer in winter can be detected in the bottle samples, although the depth of the Chl $a$ maximum tends to slightly shallower in data from bottle samples than in those from profiling floats (Figs. S3g-i and S4g-i). Therefore, a subsurface maximum within the mixed layer is not necessarily just the fluorescence maximum but also the substantial Chl $a$ maximum. This indicates that the subsurface $\mathrm{Chl} a$ maximum is a general feature of the ocean, even in areas with a deep mixed layer in winter. In fact, a sporadic stratification and the Chl $a$ maximum just below the sporadic mixed layer have been found at midlatitudes and in the subarctic in winter (Chiswell 2011; Ito et al., 2015; Matsumoto et al., 2021).

In the subtropics, nitrate concentrations were quite low even at the Chl $a$ maximum depths (Fig. 6c). Nitrate concentration is not necessarily an appropriate index of available nutrients for phytoplankton. Nitrate is used as soon as it is available in the subtropics (Lewis et al., 1986). Furthermore, biological production does not always require nitrate, and ammonium assimilation is more important in the subtropics than in the subarctic (Eppley and Peterson, 1979). Nitrogen fixation also contributes to biological production in the subtropics (Deutsch et al., 2007; Karl et al., 1997). Meanwhile, nitrate concentrations are high at the depths of the Chl $a$ maximum in the subarctic North Pacific and in the eastern tropical Pacific because the limiting nutrient for biological production is iron rather than nitrate (Landry et al., 1997; Martin and Fitzwater, 1988; Martin et al., 1990).

Oxygen oversaturation in the subtropics occurs below the mixed-layer depth and above the subsurface Chl $a$ maximum (Figs. 2d, 4c, and 5). Biological production per unit of Chl $a$ is generally more effective under high light levels (Yoder, 1979). Oxygen generated in deeper layers would be removed by the remineralization of sinking particles (Martin et al., 1987). In any case, substantial new production occurs in the subtropics. Seasonal oxygen production in the subtropical subsurface layer from winter to summer sometimes yields approximately $5-10 \mu \mathrm{mol} \mathrm{kg} \mathrm{kg}^{-1}$ of oxygen (Figs. 7f, 8c, f). When the seasonal oxygen production is integrated over the $50-150 \mathrm{~m}$ depth range, the value becomes 500-1000 $\mathrm{mmol} \mathrm{O} \mathrm{m}^{-2}$ per 6 months. Assuming a Redfield $\mathrm{O}: \mathrm{C}$ ratio of $276: 106$, this is the equivalent of $200-$ $400 \mathrm{mmol} \mathrm{C} \mathrm{m}^{-2}$ per 6 months. This is consistent with the net community production values of $1.6 \pm 0.2 \mathrm{~mol} \mathrm{C} \mathrm{m}^{-2} \mathrm{yr}^{-1}$ and $0.9 \pm 0.4 \mathrm{~mol} \mathrm{C} \mathrm{m}^{-2} \mathrm{yr}^{-1}$ reported by Riser and Johnson (2008) in the subtropical North Pacific and South Pacific, half of which occurred in the surface layer. The satellite-derived NPP in the subtropics is approximately $20 \mathrm{mmol} \mathrm{m}^{-2} \mathrm{~d}^{-1}$ and $3600 \mathrm{mmol} \mathrm{C} \mathrm{m}^{-2}$ per 6 months (not shown here). Consequently, new production derived from subsurface oxygen 

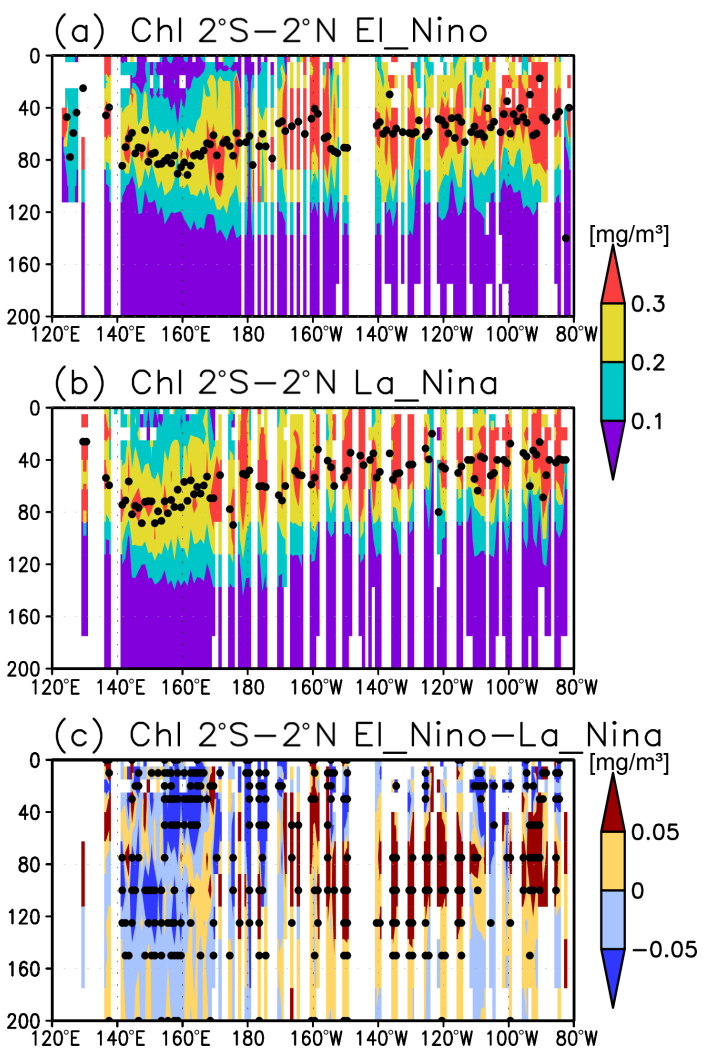

Figure 11. (a-c) Cross sections of the chlorophyll $a$ (Chl $a$ ) concentrations in the equatorial Pacific $\left(2^{\circ} \mathrm{S}\right.$ to $\left.2^{\circ} \mathrm{N}\right)$ during El Niño and La Niña and the difference between them. The black dots denote the depth of the Chl $a$ maximum in (a) and (b) and the significant difference at $5 \%$ in (c).

production in the subtropics is estimated at approximately $10 \%$ of the NPP. This is consistent with an $f$ ratio of $15 \%$ reported at station ALOHA $\left(23^{\circ} \mathrm{N} 158^{\circ} \mathrm{W}\right.$; Karl et al., 1996), considering a small but nonzero seasonal dissolved inorganic carbon drawdown reported in the subtropical surface layer (Yasunaka et al., 2013, 2021). It should be noted that oxygen production is not always associated with an increase in biomass at shallow depths in the subtropics (Fujiki et al., 2020).

A seasonal reduction in nitrate along with oxygen production in the subsurface layers cannot be inferred (not shown here) because the number and quality of nitrate observations are likely insufficient to detect such a relationship. Another possibility is that nitrogen fixation substantially contributes to biological production (Deutsch et al., 2007; Karl et al., 1997).

Lower Chl $a$ concentrations at the surface during El Niño (Fig. 12a) result from reduced upwelling of nutrient-rich subsurface water to the surface (Chavez et al., 1999). Although Matsumoto and Furuya (2011) showed that no substantial changes in the average subsurface $\mathrm{Chl} a$ concentrations in the western Pacific warm pool region were associ-
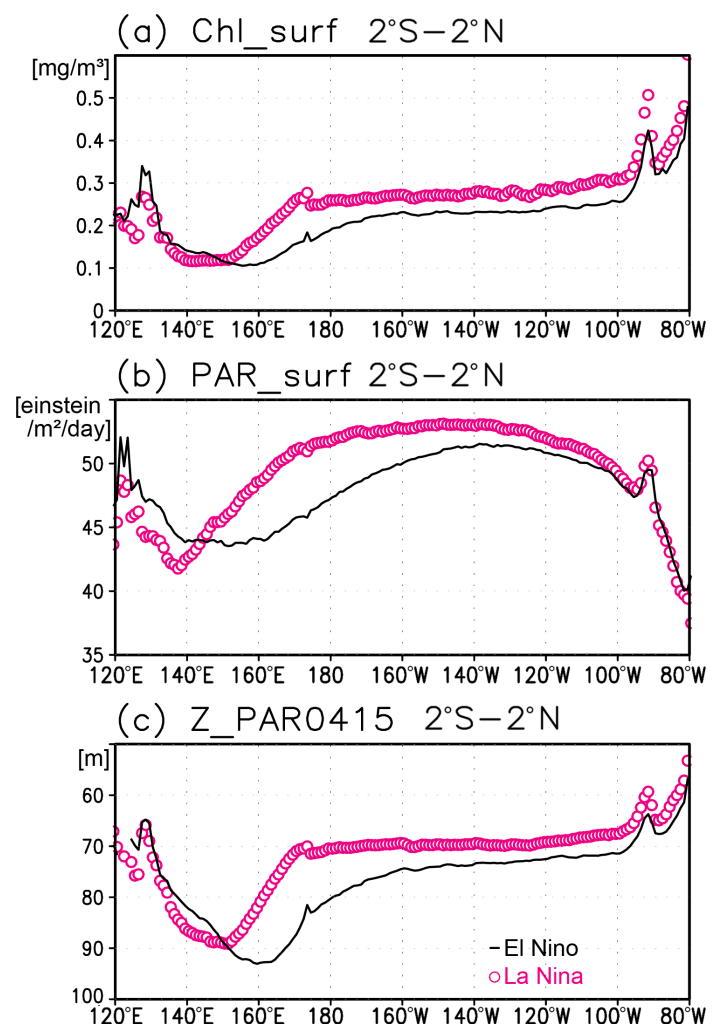

Figure 12. (a) Satellite-derived surface chlorophyll $a$ concentrations, (b) surface photosynthetically available radiation (PAR), and (c) the photosynthetically active layer $\left(>0.415 \mathrm{~mol} \mathrm{~m}^{-2} \mathrm{~d}^{-1}\right.$ of PAR) along the equatorial Pacific during El Niño (solid black lines) and La Niña (open magenta circles).

ated with ENSO, subsurface $\mathrm{Chl} a$ concentrations at the fixed grids were observed here to decrease during El Niño west of $160^{\circ} \mathrm{E}$ (Fig. 11c).

The inverse correlation of the surface and subsurface $\mathrm{Chl} a$ concentrations in the central and eastern tropical Pacific associated with ENSO (Figs. 11c and 12a) may result from a decrease in surface $\mathrm{Chl} a$ concentrations that increases light penetration to the subsurface (Fig. 12a, c). This then increases the subsurface $\mathrm{Chl} a$ concentrations, as postulated by Uitz et al. (2006). In Uitz et al. (2006), the Chl $a$ profile in stratified water is parameterized to increase the subsurface Chl $a$ concentrations with decreasing surface Chl $a$ concentrations. An inverse correlation associated with ENSO has been presented in previous model results (Lee et al., 2014; Kang et al., 2017). However, the subsurface signals in those models are much weaker than the surface signals, unlike those in this study (see Fig. 4 in Uitz et al., 2006, and Fig. 11 in Lee et al., 2014). Thus, the subsurface response to this process may have been underestimated. 


\section{Conclusions}

This study presents the first view of the global maps of subsurface Chl $a$ maxima and their seasonal variation and interannual variation associated with ENSO. Using in situ Chl $a$ concentration data, we found dynamic variability in subsurface Chl $a$ concentrations in time and space. A subsurface $\mathrm{Chl} a$ maximum was observed across the world's oceans, including a year-round stable maximum at depths greater than $80 \mathrm{~m}$ in the subtropics and tropics, a maximum below the mixed layer during summer and within the mixed layer during winter in the midlatitudes, and a maximum within the mixed layer at $45-60^{\circ} \mathrm{S}$ in the Southern Ocean and the northern North Atlantic. It extends deeper than the base of the photosynthetically active layer in the subtropics but is shallower in the tropics and midlatitudes. At the $20-40^{\circ}$ latitudinal bands, the subsurface $\mathrm{Chl} a$ maxima tend to deepen in summer with the seasonal deepening of the photosynthetically active layer. The seasonal oxygen increase below the mixed layer in the subtropics implies substantial new biological production. During El Niño, the subsurface Chl $a$ concentrations in the equatorial Pacific are higher in the middle and to the east and lower in the west than during La Niña, which is the opposite of the patterns that occur at the surface.

$\mathrm{Chl} a$ concentrations vary dynamically in time and space on the ocean surface and in the subsurface. The maps presented in this study can be used to help validate ocean biogeochemical and Earth system models and should facilitate development of models. Chl $a$ concentrations are also related to the absorption of shortwave radiation, and the vertical distribution of shortwave radiation affects the thermal structure and dynamics of the ocean (Lewis et al., 1990; Siegel et al., 1995). Therefore, continuous measurements and archiving Chl $a$ data are desirable. An increase in the coverage of biogeochemical floats with $\mathrm{Chl} a$ sensors is a promising way to generate more subsurface Chl $a$ data (Chai et al., 2020). This would help reveal the direct relationship in the subsurface layer of the world's oceans between $\mathrm{Chl} a$ concentrations and absolute light intensity (rather than the estimated light intensity described here) and between Chl $a$ concentration and biomass.

Data availability. WOD2018 was downloaded from https://www. nodc.noaa.gov/OC5/WOD/pr_wod.html (last access: 8 February 2022, NOAA, 2020a), GLODAPv2.2019 from https://www.glodap. info (last access: 8 February 2022, Bjerknes Climate Data Centre and the ICOS Ocean Thematic Centre, 2020), GlobColour_R2018 was downloaded from http://hermes.acri.fr/index.php (last access: 8 February 2022, ACRI-ST, 2020), NPP was downloaded from http://www.science.oregonstate.edu/ocean.productivity/index. php (last access: 8 February 2021, O’Malley, 2021), WOA2018 was downloaded from https://www.nodc.noaa.gov/OC5/woa18/ (last access: 8 February 2021, NOAA, 2020b), MILA_GPV was downloaded from http://www.jamstec.go.jp/ARGO/argo_web/ argo/?page_id=223andlang=en (last access: 16 March 2021, JAM-
STEC, 2020), and HadISST was downloaded from https://www. metoffice.gov.uk/hadobs/hadisst/ (last access 16 March 2021, Kennedy, 2008). Data relating to the depth of the subsurface Chl $a$ maxima presented in Fig. 2a of this paper are available online from http://caos.sakura.ne.jp/sao/scm/ (last access 8 February 2022, Yasunaka, 2021).

Supplement. The supplement related to this article is available online at: https://doi.org/10.5194/os-18-255-2022-supplement.

Author contributions. SY designed the study, conducted the analysis, and wrote the manuscript. TO conceived the study and modified the manuscript. KoS provided advice on the analysis and the manuscript. KaS helped with data management.

Competing interests. The contact author has declared that neither they nor their co-authors have any competing interests.

Disclaimer. Publisher's note: Copernicus Publications remains neutral with regard to jurisdictional claims in published maps and institutional affiliations.

Acknowledgements. The authors thank the editor and the two reviewers for their fruitful comments and Eko Siswanto for his assistance with calculating subsurface PAR.

Financial support. This research has been supported by the Japan Society for the Promotion of Science (grant no. JP18H04129).

Review statement. This paper was edited by Piers Chapman and reviewed by Emmanuel Boss and one anonymous referee.

\section{References}

ACRI-ST: GlobColour [data set], https://hermes.acri.fr/ (last access: 8 February 2022), 2020.

Anderson, O. R.: An interdisciplinary theory of behavior, J. Res. Sci. Teach., 6, 265-273, https://doi.org/10.1002/tea.3660060311, 1969.

Ardyna, M., Babin, M., Gosselin, M., Devred, E., Bélanger, S., Matsuoka, A., and Tremblay, J.-É.: Parameterization of vertical chlorophyll $a$ in the Arctic Ocean: impact of the subsurface chlorophyll maximum on regional, seasonal, and annual primary production estimates, Biogeosciences, 10, 4383-4404, https://doi.org/10.5194/bg-10-4383-2013, 2013.

Baldry K., Strutton, P. G., Hill, N. A., and Boyd, P. W.: Subsurface chlorophyll-a maxima in the Southern Ocean, Front. Mar. Sci. 7, 671, https://doi.org/10.3389/fmars.2020.00671, 2020.

Beckmann, A. and Hense, I.: Beneath the surface: Characteristics of oceanic ecosystems under weak mixing conditions 
- a theoretical investigation, Prog. Oceanogr., 75, 771-796, https://doi.org/10.1016/j.pocean.2007.09.002, 2007.

Behrenfeld, M. J. and Falkowski, P. G.: Photosynthetic rates derived from satellite-based chlorophyll concentration, Limnol. Oceanogr., 42, 1-20, https://doi.org/10.4319/lo.1997.42.1.0001, 1997.

Bhattathiri, P. M. A., Pant, A., Sawant, S. S., Gauns, M., Matondkar, S. G. P., and Mohanraju, R.: Phytoplankton production and chlorophyll distribution in the eastern and central Arabian Sea in 1994-1995, Curr. Sci., 71, 857-862, 1996.

Biermann, L., Guinet, C., Bester, M., Brierley, A., and Boehme, L.: An alternative method for correcting fluorescence quenching, Ocean Sci., 11, 83-91, https://doi.org/10.5194/os-11-83-2015, 2015.

Bjerknes Climate Data Centre and the ICOS Ocean Thematic Centre: GLODAP [data set], https://www.glodap.info/ (last access: 8 February 2022), 2020.

Boss, E. and Behrenfeld, M.: In situ evaluation of the initiation of the North Atlantic phy-toplankton bloom, Geophys. Res. Lett., 37, L18603, https://doi.org/10.1029/2010GL044174, 2010.

Boyer, T. P., Baranova, O. K., Coleman, C., Garcia, H. E., Grodsky, A., Locarnini, R. A., Mishonov, A. V., Paver, C. R., Reagan, J. R., Seidov, D., Smolyar, I. V., Weathers, K., and Zweng, M. M.: World Ocean Database 2018, edited by: Mishonov, A. V., NOAA Atlas NESDIS 87, 207pp., 2018.

Campbell, L. and Vaulot, D.: Photosynthetic picoplankton community structure in the subtropical North Pacific Ocean near Hawaii (station ALOHA), Deep Sea Res. Pt. I, 40, 2043-2060, https://doi.org/10.1016/0967-0637(93)90044-4, 1993.

Chai, F., Johnson, K.S., Claustre, H., Xing, X., Wang, Y., Boss, E., Riser, S., Fennel, K., Schofield, O., and Sutton, A.: Monitoring ocean biogeochemistry with autonomous platforms, Nat. Rev. Earth Environ., 1, 315-326, https://doi.org/10.1038/s43017020-0053-y, 2020.

Chavez, F. P., Strutton, P. G., Friederich, G. E., Feely, R. A., Feldman, G. C., Foley, D. G., and McPhaden, M. J.: Biological and chemical response of the equatorial Pacific Ocean to the 1997-98 El Niño, Science, 286, 2126-2131, https://doi.org/10.1126/science.286.5447.2126, 1999.

Chiswell, S. M.: Annual cycles and spring blooms in phytoplankton: don't abandon Sverdrup completely, Mar. Ecol. Prog. Ser., 443, 39-50, https://doi.org/10.3354/meps09453, 2011.

Cornec, M, Claustre, H., Mignot, A., Guidi, L., Lacour, L., Poteau, A., D’Ortenzio, F., Gentili, B., and Schmechtig, C.: Deep Chlorophyll Maxima in the Global Ocean: Occurrences, Drivers and Characteristics, Global Biogeochem. Cy., 35, e2020GB006759, https://doi.org/10.1029/2020GB006759, 2021.

Cullen, J. J.: Subsurface chlorophyll maximum layers: Enduring enigma or mystery solved?, Annu. Rev. Mar. Sci., 7, 207-239, https://doi.org/10.1146/annurev-marine-010213-135111, 2015.

Deutsch, C., Sarmiento, J. L., Sigman, D. M., Gruber, N., and Dunne, J. P.: Spatial coupling of nitrogen inputs and losses in the ocean, Nature, 445, 163-167, https://doi.org/10.1038/nature05392, 2007.

Dunstan, P.K., Foster, S. D., King, E., Risbey, J., O'Kane, T. J., Monselesan, D., Hobday, A. J., Hartog J. R., and Thompson, P. A.: Global patterns of change and variation in sea surface temperature and Chlorophyll $a$, Sci. Rep., 8, 14624, https://doi.org/10.1038/s41598-018-33057-y, 2018.
Eppley, R. W. and Peterson, B. J.: Particulate organic matter flux and planktonic new production in the deep ocean, Nature, 282, 677-680, https://doi.org/10.1038/282677a0, 1979.

Falkowski, P. G. and Kolber, Z.: Variations in chlorophyll fluorescence yields in phytoplankton in the world oceans, Funct. Plant Biol., 22, 341-355, https://doi.org/10.1071/PP9950341, 1995.

Fennel, K. and Boss, E.: Subsurface maxima of phytoplankton and chlorophyll: Steady-state solutions from a simple model, Limnol. Oceanogr., 48, 1521-1534, https://doi.org/10.4319/lo.2003.48.4.1521, 2003.

Frouin, R., Franz, B., and Werdell, P.: The SeaWiFS PAR product, Algorithm updates for the fourth SeaWIFS data reprocessing, NASA/TM 2003-206892, 22, 46-50, 2003.

Fujiki, T., Inoue, R., Honda, M. C., Wakita, M., Mino, Y., Sukigara, C., and Abe, O.: Time-series observations of photosynthetic oxygen production in the subtropical western North Pacific by an underwater profiling buoy system, Limnol. Oceanogr., 65, 10721084, https://doi.org/10.1002/lno.11372, 2020.

Furuya, K.: Subsurface chlorophyll maximum in the tropical and subtropical western Pacific Ocean: Vertical profiles of phytoplankton biomass and its relationship with Chlorophyll $a$ and particulate organic carbon, Mar. Biol., 107, 529-539, https://doi.org/10.1007/BF01313438, 1990.

Garcia, H. E., Weathers, K., Paver, C. R., Smolyar, I., Boyer, T. P., Locarnini, R. A., Zweng, M. M., Mishonov, A. V., Baranova, O. K., Seidov, D., and Reagan, J. R.: World Ocean Atlas 2018, Volume 3: Dissolved Oxygen, Apparent Oxygen Utilization, and Oxygen Saturation, edited by: Mishonov, A., NOAA Atlas NESDIS 83, 38 pp., 2018a.

Garcia, H. E., Weathers, K., Paver, C. R., Smolyar, I., Boyer, T. P., Locarnini, R. A., Zweng, M. M., Mishonov, A. V., Baranova, O. K., Seidov, D., and Reagan, J. R.: World Ocean Atlas 2018, Volume 4: Dissolved Inorganic Nutrients (phosphate, nitrate and nitrate+nitrite, silicate), edited by: Mishonov, A., NOAA Atlas NESDIS 84, 35 pp., 2018 b.

Goldman, J. C.: Spatial and temporal discontinuities of biological processes in pelagic surface waters, in: Toward a theory on biological-physical interactions in the world ocean, edited by: Rothschild, B. J., NATO ASI Series (Series C: Mathematical and Physical Sciences), 239, Springer, Dordrecht, https://doi.org/10.1007/978-94-009-3023-0_15, 1988.

Gomi, Y., Taniguchi, A., and Fukuchi, M.: Temporal and spatial variation of the phytoplankton assemblage in the eastern Indian sector of the Southern Ocean in summer 2001/2002, Polar Biol., 30, 817-827, https://doi.org/10.1007/s00300-006-0242-2, 2007.

Hosoda, S., Ohira, T., Sato, K., and Suga, T.: Improved description of global mixed-layer depth using Argo profiling floats, J. Oceanogr., 66, 773-787, https://doi.org/10.1007/s10872-0100063-3, 2010.

Itoh, S., Yasuda, I., Saito, H., Tsuda, A., and Komatsu, K.: Mixed layer depth and Chlorophyll $a$ : Profiling float observations in the Kuroshio-Oyashio Extension region, J. Mar. Syst., 151, 1-14, https://doi.org/10.1016/j.jmarsys.2015.06.004, 2015.

JAMSTEC: MILA_GPV, http://www.jamstec.go.jp/ARGO/argo_ web/argo/?page_id=223andlang=en (last access: 16 March 2021), 2020.

Jochum, M., Yeager, S., Lindsay, K., Moore, K., and Murtugudde, R.: Quantification of the Feedback between Phytoplankton and 
ENSO in the Community Climate System Model, J. Climate, 23, 2916-2925, https://doi.org/10.1175/2010JCLI3254.1, 2010.

Kang, X., Zhang, R. H., Gao, C., and Zhu, J.: An improved ENSO simulation by representing chlorophyll-induced climate feedback in the NCAR Community Earth System Model, Sci. Rep., 7, 17123, https://doi.org/10.1038/s41598-017-17390-2, 2017.

Karl, D. M., Christian, J. R., Dore, J. E., Hebel, D. V., Letelier, R. M., Tupas, L. M., and Winn, C. D.: Seasonal and interannual variability in primary production and particle flux at Station ALOHA, Deep Sea Res. Pt II, 43, 539-568, https://doi.org/10.1016/0967-0645(96)00002-1, 1996.

Karl, D., Letelier, R., Tupas, L., Dore, J., Christian, J., and Hebel, D.: The role of nitrogen fixation in biogeochemical cycling in the subtropical North Pacific Ocean, Nature, 388, 533-538, https://doi.org/10.1038/41474, 1997.

Kennedy, J.: Hadley Centre Sea Ice and Sea Surface Temperature data set, https://www.metoffice.gov.uk/hadobs/hadisst/ (last access 16 March 2021), 2020.

Kitchen, J. C. and Zaneveld, J. R. V.: On the noncorrelation of the vertical structure of light scattering and Chlorophyll $a$ in case 1 waters, J. Geophys. Res.-Oceans, 95, 20237-20246, https://doi.org/10.1029/JC095iC11p20237, 1990.

Landry, M. R., Barber, R. T., Bidigare, R. R., Chai, F., Coale, K. H., Dam, H. G., Lewis, M. R., Lindley, S. T., McCarthy, J. J., Roman, M. R., Stoecker, D. K., Verity, P. G., and White, J. R.: Iron and grazing constraints on primary production in the central equatorial Pacific: An EqPac synthesis, Limnol. Oceanogr., 42, 405-418, https://doi.org/10.4319/lo.1997.42.3.0405, 1997.

Lee, K. W., Yeh, S. W., Kug, J. S., and Park, J. Y.: Ocean chlorophyll response to two types of El Niño events in an oceanbiogeochemical coupled model, J. Geophys. Res.-Oceans, 119, 933-952, https://doi.org/10.1002/2013JC009050, 2014.

Letelier, R. M., Karl, D. M., Abbott, M. R., and Bidigare, R. R.: Light driven seasonal patterns of Chlorophyll and nitrate in the lower euphotic zone of the North Pacific Subtropical Gyre, Limnol. Oceanogr., 49, 508-519, https://doi.org/10.4319/lo.2004.49.2.0508, 2004.

Lewis, M. R., Hebert, D., Harrison, W. G., Platt, T., and Oakey, N. S.: Vertical nitrate fluxes in the oligotrophic ocean, Science, 234, 870-873, https://doi.org/10.1126/science.234.4778.870, 1986.

Lewis, M. R., Carr, M. -E., Feldman, G. C., Esaias, W., and McClain, C. R.: Influence of penetrating solar radiation on the heat budget of the equatorial Pacific Ocean, Nature, 347, 543-545, https://doi.org/10.1038/347543a0, 1990.

Lin, P., Chai, F., Xue, H., and Xiu, P.: Modulation of decadal oscillation on surface chlorophyll in the Kuroshio Extension, J. Geophys. Res.-Oceans, 119, 187-199, https://doi.org/10.1002/2013JC009359, 2014.

Mann, K. H. and Lazier, J. R.: Dynamics of marine ecosystems: Biological-physical interactions in the ocean, 2nd Edn., Blackwell Sci., Mal-den, Mass, https://doi.org/10.1017/S0025315400072003, 1996.

Maritorena, S., d'Andon, O. F., Mangin, A., and Siegel, D.: Merged satellite ocean color data products using a bio-optical model: Characteristics, benefits and issues, Remote Sens. Environ., 114, 1791-1804, https://doi.org/10.1016/j.rse.2010.04.002, 2010.

Martin, J. and Fitzwater, S.: Iron deficiency limits phytoplankton growth in the north-east Pacific subarctic, Nature, 331, 341-343, https://doi.org/10.1038/331341a0, 1988.
Martin, J., Knauer, G., Karl, D., and Broenkow, W.: VERTEX: Carbon cycling in the northeast Pacific, Deep Sea Res., 34, 267-285, https://doi.org/10.1016/0198-0149(87)90086-0, 1987.

Martin, J., Gordon, R., and Fitzwater, S.: Iron in Antarctic waters, Nature, 345, 156-158, https://doi.org/10.1038/345156a0, 1990.

Masuda, Y., Yamanaka, Y., Smith, S. L., Hirata, T., Nakano, H., Oka, A., and Sumata, H.: Photoacclimation by phytoplankton determines the distribution of global subsurface chlorophyll maxima in the ocean, Commun. Earth Environ., 128, 2, https://doi.org/10.1038/s43247-021-00201-y, 2021.

Matsumoto K. and Furuya, K.: Variations in phytoplankton dynamics and primary production associated with ENSO cycle in the western and central equatorial $\mathrm{Pa}-$ cific during 1994-2003, J. Geophys. Res., 116, C12042, https://doi.org/10.1029/2010JC006845, 2011.

Matsumoto, K., Sasai, Y., Sasaoka, K., Siswanto, E., and Honda, M. C.: The formation of subtropical phytoplankton blooms is dictated by water column stability during winter and spring in the oligotrophic northwestern North Pacific, J. Geophys. Res., 126, e2020JC016864, https://doi.org/10.1029/2020JC016864, 2021.

Mignot, A., Claustre, H., Uitz, J., Poteau, A., D’Ortenzio, F., and Xing, X.: Understanding the seasonal dynamics of phytoplankton biomass and the deep chlorophyll maximum in oligotrophic environments: A Bio-Argo float investigation, Global Biogeochem. Cy., 28, 856-876, https://doi.org/10.1002/2013GB004781, 2014.

Moeller, H. V., Laufkötter, C., Sweeney, E. M., and Johnson, M. D.: Light-dependent grazing can drive formation and deepening of deep chlorophyll maxima, Nat. Commun., 10, 1978, https://doi.org/10.1038/s41467-019-09591-2, 2019.

Morel, A., Huot, Y., Gentili, B., Werdell, P. J., Hooker, S. B., and Franz, B. A.: Examining the consistency of products derived from various ocean color sensors in open ocean (Case 1) waters in the perspective of a multi-sensor approach, Remote Sens. Environ., 111, 69-88, https://doi.org/10.1016/j.rse.2007.03.012, 2007.

Nishioka, J. and Obata, H.: Dissolved iron distribution in the western and central subarctic Pacific: HNLC water formation and biogeochemical processes, Limnol. Oceanogr., 62, 2004-2022, 2017.

Nishioka, J., Obata, H., Ogawa, H., Ono, K., Yamashita, Y., Lee, K., Takeda, S., and Yasuda, I.: Subpolar marginal seas fuel the North Pacific through the intermediate water at the termination of the global ocean circulation, P. Natl. Acad. Sci. USA, 117, 12665-12673, https://doi.org/10.1073/pnas.2000658117, 2020.

NOAA: World Ocean Database [data set], https://www.ncei.noaa. gov/products/world-ocean-database (last access: 8 February 2022), 2020a.

NOAA: World Ocean Atlas, https://www.ncei.noaa.gov/products/ world-ocean-atlas (last access: 8 February 2021), 2020 b.

Olsen, A., Lange, N., Key, R. M., Tanhua, T., Álvarez, M., Becker, S., Bittig, H. C., Carter, B. R., Cotrim da Cunha, L., Feely, R. A., van Heuven, S., Hoppema, M., Ishii, M., Jeansson, E., Jones, S. D., Jutterström, S., Karlsen, M. K., Kozyr, A., Lauvset, S. K., Lo Monaco, C., Murata, A., Pérez, F. F., Pfeil, B., Schirnick, C., Steinfeldt, R., Suzuki, T., Telszewski, M., Tilbrook, B., Velo, A., and Wanninkhof, R.: GLODAPv2.2019an update of GLODAPv2, Earth Syst. Sci. Data, 11, 1437-1461, https://doi.org/10.5194/essd-11-1437-2019, 2019. 
O’Malley, R.: Ocean Productivity [data set], http://sites.science. oregonstate.edu/ocean.productivity/index.php (last access: 8 February 2021), 2021.

Pedlosky, J.: The dynamics of the oceanic subtropical gyres, Science, 248, 316-322, https://doi.org/10.1126/science.248.4953.316, 1990.

Rayner, N. A. A., Parker, D. E., Horton, E. B., Folland, C. K., Alexander, L. V., Rowell, D. P., Kent, E. C., and Kaplan, A.: Global analyses of sea surface temperature, sea ice, and night marine air temperature since the late nineteenth century, J. Geophys. Res., 108, 4407, https://doi.org/10.1029/2002JD002670, 2003.

Riser, S. C. and Johnson, K. S.: Net production of oxygen in the subtropical ocean, Nature, 451, 323-325, https://doi.org/10.1038/nature06441, 2008.

Saijo, Y., Iizuka, S., and Asaoka, O.: Chlorophyll maxima in Kuroshio and adjacent area, Mar. Biol., 4, 190-196, https://doi.org/10.1007/BF00393892, 1969.

Sasaoka, K., Chiba, S., and Saino, T.: Climatic forcing and phytoplankton phenology over the subarctic North Pacific from 1998 to 2006, as observed from ocean color data, Geophys. Res. Lett., 38, L15609, https://doi.org/10.1029/2011GL048299, 2011.

Séférian, R., Berthet, S., Yool, A., Palmiéri, J., Bopp, L., Tagliabue, A., Kwiatkowski, L., Aumont, O., Christian, J., Dunne, J., Gehlen, M., Ilyina, T., John, J. G., Li, H., Long, M.C., Luo, J. Y., Nakano, H., Romanou, A., Schwinger, J., Stock, C., Santana-Falcón, Y., Takano, Y., Tjiputra, J., Tsujino, H., Watanabe, M., Wu, T., Wu, F., and Yamamoto, A.: Tracking Improvement in Simulated Marine Biogeochemistry Between CMIP5 and CMIP6, Curr. Clim. Change Rep., 6, 95-119, https://doi.org/10.1007/s40641-020-00160-0, 2020.
Siegel, D. A., Ohlmann, J. C., Washburn, L., Bidigare, R. R., Nosse, C. T., Fields, E., and Zhou, Y.: Solar radiation, phytoplankton pigments and the radiant heating of the equatorial Pacific warm pool, J. Geophys. Res., 100, 4885-4891, https://doi.org/10.1029/94JC03128, 1995.

Sverdrup, H. U.: On conditions for the vernal blooming of phytoplankton, ICES J. Mar. Sci., 18, 287-295, https://doi.org/10.1093/icesjms/18.3.287, 1953.

Trenberth, K. E.: The definition of El Niño, B. Am. Meteorol. Soc., 78, 2771-2778, https://doi.org/10.1175/15200477(1997)078<2771:TDOENO>2.0.CO;2, 1997.

Uitz, J., Claustre, H., Morel, A., and Hooker, S. B.: Vertical distribution of phytoplankton communities in open ocean: An assessment based on surface chlorophyll, J. Geophys. Res., 111, 1-23, https://doi.org/10.1029/2005jc003207, 2006.

Yasunaka, S., Nojiri, Y., Nakaoka, S., Ono, T., Mukai, H., and Usui, N.: Monthly maps of sea surface dissolved inorganic carbon in the 695 North Pacific: Basin-wide distribution and seasonal variation, J. Geophys. Res.-Oceans, 118, 3843-3850, https://doi.org/10.1002/jgrc.20279, 2013.

Yasunaka, S.: Subsurface Chlorophyll Maximum [data set], http: //caos.sakura.ne.jp/sao/scm/ (last access 8 February 2022), 2021.

Yasunaka, S., Mitsudera, H., Whitney, F., and Nakaoka, S.: Nutrient and dissolved inorganic carbon variability in the North Pacific, J. Oceanogr., 77, 3-16, https://doi.org/10.1007/s10872-020-005617, 2021.

Yoder, J. A.: Effect of temperature on light-limited growth and chemical composition of Skeletonema costatum (Bacillariophyceae), J. Phycol., 15, 362-370, https://doi.org/10.1111/j.1529-8817.1979.tb00706.x, 1979. 